\title{
UNSUR-UNSUR DINAMIS PEMBELAJARAN FASILITAS BELAJAR DAN MOTIVASI BERPRESTASI TERHADAP KEPUASAN SISWA MTS
}

\author{
Muhammad Hatta \\ MTs Ta'mirul Islam Surakarta \\ hattamuhammad1975@gmail.com
}

\begin{abstract}
The purpose of this study there are four, the first test and analyze the contribution of dynamic elements of learning, learning, and achievement motivation on student satisfaction, second, test and analyze the contribution of dynamic elements of learning to student satisfaction, third, test and analyze the contribution of learning facility to the satisfaction of the students, the fourth test and analyze the contribution of achievement motivation on student satisfaction. Quantitative research, research design ex-post facto by the correlation technique. Research conducted at MTs Ta 'mirul Islam Surakarta in the second semester of the school year 2015/2016 with a sample of 105 students. The sampling technique using proportional random sampling using krecii table. Data collection techniques in this study using questionnaires and observation. Data analysis techniques used in this research is multiple regression analysis after classical assumption test such as the test for normality, linearity test, test multicollinearity, heteroscedasticity test and autocorrelation test.The results of the study there were four, (1) there are contribution dynamic elements of learning, learning, and achievement motivation in a significant 0.05 on student satisfaction was $27.5 \%$, (2) there is a contributions dynamic elements of learning at 0.048 significant on student satisfaction and contribute effectively amounted to $6.49 \%$, (3) there is a significant contribution of the teaching facilities at 0,012 to student satisfaction and contribute effectively amounted to $9.69 \%$, (4) there is a significant contribution to the achievement motivation 0.05 on student satisfaction and contribute effectively $11.32 \%$.
\end{abstract}

Keywords: learning facilities, achievement motivation, learning dynamic element, satisfaction

\begin{abstract}
ABSTRAK
Tujuan penelitian ini ada empat, pertama menguji dan menganalisis kontribusi unsur-unsur dinamis pembelajaran, fasilitas belajar, dan motivasi berprestasi terhadap kepuasan siswa, kedua, menguji dan menganalisis kontribusi unsur-unsur dinamis pembelajaran terhadap kepuasan siswa, ketiga, menguji dan menganalisis kontribusi fasilitas belajar terhadap kepuasan siswa,keempat menguji dan menganalisis kontribusi motivasi berprestasi terhadap kepuasan siswa. Jenis penelitian kuantitatif, dengan desain penelitian ex-post facto dengan teknik korelasional - Penelitian dilaksanakan di MTs Ta' mirul Islam Surakarta pada semester genap tahun pelajaran 2015/2016dengan sampel 105 siswa. Teknik pengambilan sampel
\end{abstract}


menggunakan proposional random sampling dengan menggunakan tabel kracjie. Teknik pengumpulan data dalam penelitian ini menggunakan metode angket dan observasi. Teknik analisis data yang digunakan dalam penelitian ini analisis regresi ganda setelah sebelumnya dilakukan uji asumsi klasik seperti uji normalitas, uji linieritas, uji multikolinieritas, uji heteroskedastisitas dan uji autokorelasi.Hasil penelitian ada empat, (1) ada kontribusi unsur-unsur dinamis pembelajaran, fasilitas belajar, dan motivasi berprestasi pada signifikan 0,05 terhadap kepuasan siswa sebesar 27,5\%, (2) ada kontribusi unsur-unsur dinamis pembelajaran pada signifikan 0,048 terhadap kepuasan siswa dan memberikan sumbangan efektif sebesar 6,49\%, (3) ada kontribusi fasilitas belajar pada signifikan 0,012 terhadap kepuasan siswa dan memberikan sumbangan efektif sebesar 9,69\%,(4) ada kontribusi motivasi berprestasi pada signifikan 0,05 terhadap kepuasan siswa dan memberikan sumbangan efektif sebesar $11,32 \%$.

Kata Kunci: fasilitas belajar, motivasi berprestasi, unsur dinamis pembelajaran, kepuasan

\section{PENDAHULUAN}

Pelayanan proses belajar mengajar yang bermutu adalah pelayanan proses belajar mengajar yang dapat menciptakan suasana pembelajaran kelas yang kondusif dan mendorong siswa untuk berperan aktif. Dengan demikian, dalam pelaksanaannya diperlukan strategi dan metode belajar mengajar yang sesuai dengan materi ajar. Pelayanan proses belajar mengajar yang menggunakan semua fasilitas belajar yang optimal dapat menimbulkan perasaan bahwa siswa akan merasa mendapatkan keuntungan sewaktu pelajaran yang disampaikan difokuskan untuk menghasilkan kemampuan kognitif yang tinggi.

Mutu proses belajar mengajar merupakan mutu dari aktivitas mengajar yang dilakukan oleh guru dan siswa baik didalam kelas maupun diluar kelas dengan menerapkan suatu manajemen mutu. Penerapan manajemen mutu dalam pendidikan ini lebih populer dengan sebutan istilah Total Quality Education (TQE). Dasar dari manajemen ini dikembangkan dari konsep Total Quality Management (TQM), yang mulanya diterapkan pada dunia bisnis kemudian diterapkan pada dunia pendidikan. Secara filosofis, konsep ini menekankan pada pencarian secara konsisten terhadap perbaikan yang berkelanjutan untuk mencapai kebutuhan dan kepuasan pelanggan (Sallis ,2012: 5). Hal yang terpenting dari kepuasan siswa adalah dampak dari ketercapaian kepuasan yang dirasakan oleh siswa atas pelayanan pendidikan yang diberikan oleh sekolah karena dengan tercapainya kepuasan siswa maka mereka dapat meningkatkan kinerja belajar siswa sehingga akan dapat mencapai prestasi belajar yang tinggi.

Hasil penelitian Osman Sahin(2014), mereka menyatakan bahwa ada beberapa siswa yang umumnya puas dengan fasilitas asrama dengan skor rata-rata 2,42 pada skala lima poin yang mewakili tingkat ketidakpuasan $66,6 \%$ serta tidak semua fasilitas ternyata yang diperlukan. Sementara itu menurut Seng (2013) dalam penelitiannya menjelaskan bahwa kepuasan dapat tercermin dari layanan fasilitas yang disediakan oleh sekolah, artinya bahwa kepuasan siswa dipengaruhi oleh aktifitas sekolah mereka, seperti lingkungan akademik, personil pengajaran 
yang efektif. Penelitian ini di desain menggunakan penelitian deskriptif kualitatif.

Menurut Sopiatin (2010:106), pendidikan bermutu dapat menghasilkan lulusan bermutu yang sesuai dengan standar kelulusan yang ditetapkan. Dalam upaya meningkatkan mutu lulusan sekolah maka diperlukan perbaikan mutu pendidikan berbasis sekolah yang difokuskan pada kepuasan siswa. Artinya, perbaikan mutu ini diarahkan kepada pemenuhan kebutuhan dan harapan siswa. Kepuasan siswa merupakan suatu sikap positif siswa terhadap pelayanan proses belajar mengajar yang dilaksanakan oleh guru karena adanya kesesuaian antara apa yang diharapkan dan dibutuhkan dengan kenyataan yang diterimanya.

Kepuasan siswa sangat tergantung pada persepsi dan harapan mereka terhadap sekolah yang dipengaruhi oleh kebutuhan akan pendidikan melalui proses pembelajarannya dan keinginan untuk dapat berprestasi serta melanjutkan ke jenjang pendidikan yang lebih tinggi, termasuk pengalaman yang dirasakan oleh teman temannya atau kakak kelasnya atas fasilitas belajar yang ada disekolah dan adanya komunikasi melalui iklan dan pemasaran. Senada dengan hal tersebut, penelitian Diana Rahmawati (2013) tentang analisis faktor-faktor yang mempengaruhi kepuasan mahasiswamenghasilkan indikator yang paling dominan adalah indikator profesionalisme dosen dalam proses pembelajaran.

Pada perspektif kognitif, motivasi yang lebih signifikan bagi siswa adalah motivasi intrinsik, karena lebih murni dan tidak tergantung pada orang lain. Dengan demikian guru beserta orang tua juga berperan dalam membangkitkan motivasi berprestasi siswa agar bersemangat belajar dalam rangka mencapai kepuasan.

Kepuasan siswa merupakan suatu sikap positif siswa terhadap pelayanan proses belajar mengajar yang dilaksanakan oleh guru karena adanya kesesuaian antara apa yang diharapkan dan dibutuhkan dengan kenyataan yang diterimanya. Pendidikan atau sekolah yang berkualitas akan mampu melaksanakan proses pematangan kualitas siswa dalam hal ini prestasi, baik prestasi akademik maupun prestasi dibidang lain serta menghasilkan lulusan yang sesuai dengan harapan, sehingga mencerminkan kepuasan siswa. Beberapa keluhan dari siswa terkait dengan penyediaan fasilitas belajar yang kurang memadahi, buku-buku penunjang diperpustakaan kurang lengkap, ruang laboratorium praktikum yang kurang nyaman dan kurang disiplinnya guru dalam memenuhi proses pembelajarannya dikelas serta kurang dapatnya guru dalam menumbuhkan motivasi untuk belajar lebih baik sehingga harapan siswa berprestasi bisa terwujud.

Berdasarkan permasalahan tersebut, maka tujuan dari penelitian ini adalah (1)untuk menguji dan menganalisis kontribusi unsur-unsur dinamis pembelajaran, fasilitas belajar, dan motivasi berprestasi siswa kelas VIII MTs Ta' mirul Islam Surakarta baik secara simultan, (2) untuk menguji dan menganalisis kontribusi unsur-unsur dinamis pembelajaran siswa kelas VIII MTs Ta' mirul Islam Surakarta secara parsial, (3) untuk menguji dan menganalisis kontribusi fasilitas belajar siswa kelas VIII MTs Ta' mirul Islam Surakarta secara parsial, dan (4) untuk menguji dan menganalisis kontribusi motivasi berprestasi siswa kelas VIII MTs Ta' mirul Islam Surakarta secara parsial.

\section{METODE}

Penelitian ini dilaksanakan di MTs Ta' mirul Islam Surakarta, dengan alasan belum pernah dijadikan tempat penelitian mengenai permasalahan yang sama dengan penelitian 
ini. Penelitian dilaksanakan dari bulan Maret sampai Mei 2016. Jenis penelitian ini adalah kuantitatif yang digunakan untuk menguji suatu teori, untuk menyajikan fakta dan untuk menunjukkan hubungan antar variabel(Subana, 2011: 25). Penelitian ini tergolong penelitian ex-post facto dengan teknik korelasional, penelitian ini tidak melakukan manipulasi terhadap gejala yang diteliti dan gejalanya secara wajar sudah ada dilapangan.(Sutama, 2015: 53). Pada penelitian ini variabel bebasnya terdiri dari unsur-unsur dinamis pembelajaran, fasilitas belajar dan motivasi berprestasi. Sedangkan variabel terikatnya adalah kepuasan siswa.

Populasi dalam penelitian ini adalah siswa kelas VIII MTs Ta' mirul Islam Surakarta tahun pelajaran 2015/2016 yang berjumlah 150 siswa. Sedangkan besarnya sampel ada 105 siswa. Teknik pengambilan sampel yang digunakan dalam penelitian ini adalah proporsional random sampling, dimana penentuan sampel memiliki karakteristik sendiri-sendiri dari populasi yang ada. (Sutama,2015:101)

Pengumpulan data menggunakan kuesioner dengan model check list $(\sqrt{ })$, responden memberi jawaban sesuai dengan pilihan yang telah disediakan. Sebelum kuesioner digunakan dalam penelitian, maka terlebih dahulu dilakukan uji validitas dan uji reliabilitas. Teknik korelasi product moment digunakan dalam perhitungan uji validitas data tiap-tiap variabel. Sedangkan uji reliabilitas data menggunakan teknik alfa cronbach.(Sugiyono, 2012 : 365)

Teknik analisis data yang digunakan adalah analisis regresi linier sederhana dan analisis regresi linier ganda. Analisis regresi linier sederhana dalam penelitian ini digunakan untuk menguji dan menganalisis kontribusi tiap-tiap variabel bebas terhadap variabel terikatnya secara parsial. Sedangkan analisis regresi linier ganda digunakan untuk menguji dan menganalisis secara simultan atau secara bersama-sama ketiga variabel bebas terhadap variabel terikatnya. (Sugiyono, $2012: 260$ )

Namun sebelum melakukan analisis regresi, terlebih dahulu melakukan uji persyaratan analisis yaitu uji normalitas, uji linieritas, uji multikolinieritas, uji heteroskedastisitas, dan uji autokorelasi.

\section{HASIL DAN PEMBAHASAN}

Data penelitian dianalisis dengan menggunakan statistik deskriptif. Pada data distribusi frekuensi untuk variabel kepuasan siswa terlihat bahwa nilai mean data tersebut 86,09 dengan median 86 dan modus datanya 85 . Angka ini menunjukkan adanya hubungan empiris antara mean, median, dan modus. Penyebaran data tidak bersifat simetris menyebabkan mayoritas data cenderung mendekati modusnya. Jika dibandingkan dengan nilai data maksimum 116 dan nilai data minimumnya 54, maka dengan nilai median 86 data ini tergolong baik. Jika digambarkan dengan kurva maka akan terlihat seperti dibawah ini.

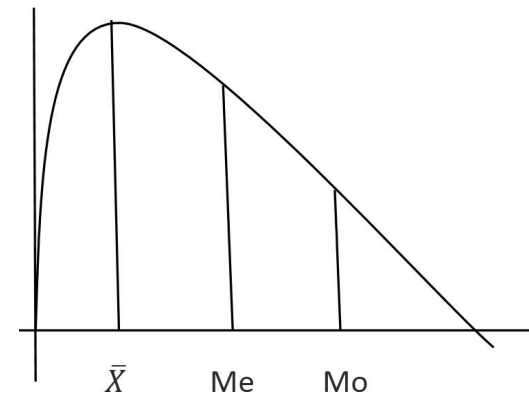


Nilai Modus $<$ Median $<$ Mean, atau $85<86<86,09$ maka kurva cenderung menceng kekanan, ini memberi makna bahwa sebaran data lebih ke arah kanan atau data ini tergolong baik karena posisi responden berada pada kepuasan rata-rata (condong negatif). Data variabel unsur-unsur dinamis pembelajaran pada tabel distribusi frekuensi menghasilkan nilai mean 71,07 dengan median 71,72 dan modusnya 72,73 menunjukkan adanya hubungan empiris diantara mean, median dan modusnya. Angka ini memberi makna bahwa penyebaran data juga tidak simetris sehingga jika digambarkan dengan kurva, maka data akan cenderung condong pada modusnya.

Dilihat dari data maksimum 88 dan data minimumnya 32, maka data unsur-unsur dinamis pembelajaran tergolong baik. Jika digambarkan dengan kurva maka akan terlihat seperti dibawah ini.

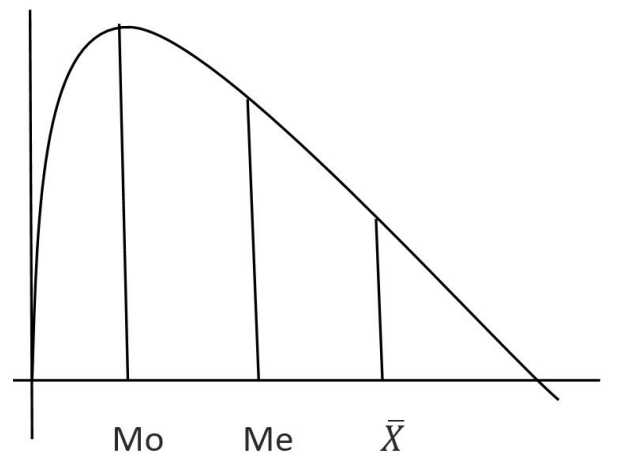

Mean $<$ Median $<$ Modus, atau 71,07 $<71,72<72,73$ maka kurva cenderung menceng kekanan, ini memberi makna bahwa sebaran data lebih cenderung ke kanan (condong negatif) dan posisi responden dalam kondisi yang baik bila dilihat dari jangkauan datanya.

Unsur-unsur dinamis pembelajaran setelah dianalisis dengan uji $\mathrm{t}$ dengan probabilitas signifikan pada 0,149, ini bermakna semakin tercipta secara baik unsur-unsur dinamis pembelajaran dalam proses pelaksanaan pembelajarannya maka semakin tinggi pula tingkat kepuasan siswa dan memberikan sumbangan efektif sebesar 6,49\% serta memberikan sumbangan relatif sebesar $23,59 \%$. Hal ini sejalan dengan penelitian yang dilakukan oleh Iglesias dan Torres (2005) yang menyatakan bahwa unsur pengajaran, metode mengajar dan tugas-tugas administratif dari seorang tenaga pendidik merupakan faktor atau aspek kunci dari kepuasan mahasiswa atau siswa.

Penelitian lain yang mendukung dari Kirmizi (2015)tentang kesiapan peserta didik dalam proses pembelajaran berkontribusi positif terhadap kepuasan siswa dan keberhasilan siswa. Dengan koefisien korelasi 0,88 menunjukkan bahwa unsur-unsur dinamis pembelajaran yang berupa kesiapan siswa dalam belajar bisa mempengaruhi keberhasilan belajar yang berakibat pada kepuasan belajar siswa. Senada dengan penelitian Puspayani (2012), yang menghasilkan bahwa kompetensi keprofesionalan seorang guru berkontribusi terhadap kepuasan siswa sebesar 39,4\%.

Penelitian disekolah ini membahas juga kontribusi dari unsur-unsur dinamis pembelajaran terhadap kepuasan siswa. Berdasarkan perhitungan analisis secara parsial diperoleh signifikan $\rho>0,05$ artinya ada kontribusi yang signifikan antara unsur-unsur dinamis pembelajaran dengan kepuasan siswa.

Data tabel distribusi selanjutnya variabel fasilitas belajar, nilai mean diperoleh 56 dan nilai 
mediannya 55,20 dengan modus 50,45. Penyebaran data tidak simetris, dan data cenderung mendekati meannya jika digambarkan pada suatu kurva.

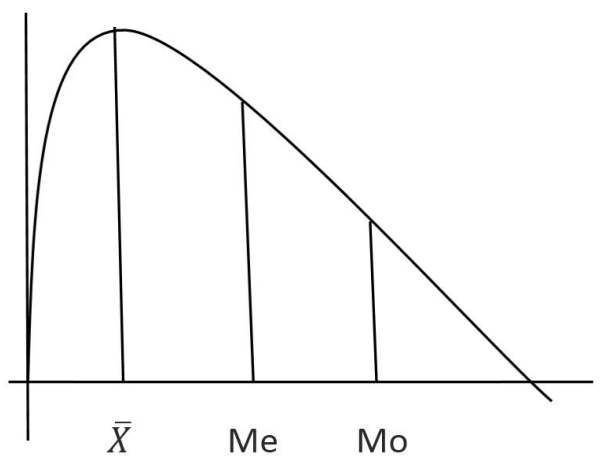

Modus $<$ Median $<$ Mean, atau 50,45 < 55,20 < 56 maka kurva cenderung menceng ke kanan, ini memberi makna bahwa sebaran data lebih cenderung ke meannya atau data ini tergolong baik dan posisi responden berada diatas rata-rata bila dilihat dari data maksimum 76 dan data minimumnya 32.

Fasilitas belajar setelah dianalisis dengan uji t dengan probabilitas signifikan pada 0,118 memberikan sumbangan efektif sebesar 9,69\% dan memberikan pula sumbangan relatif sebesar 35,24 \%, artinya semakin baik atau bertambah lengkapnya fasilitas belajar bagi para siswa, maka semakin tinggi pula tingkat kepuasan siswa. Penelitian ini didukung oleh Uka (2014) yang menyatakan bahwa kepuasan siswa dapat ditinjau dari bagaimana lingkungan fisik sekolah dan pelayanan yang disediakan oleh lembaga pendidikan tersebut. Ketika lembaga pendidikan tersebut menyelenggarakan fasilitas belajar atau pelayanan yang baik serta memenuhi semua fasilitas belajar yang diperlukan siswa dalam rangka memperoleh prestasi yang baik sehingga kepuasan siswa terpenuhi.

Bayu (2014) dalam penelitiannya menghasilkan bahwa kualitas layanan akademik mempengaruhi kepuasan mahasiswa dengan memberikan kontribusi sebesar 55,3\%. Penelitian ini mendukung penelitian yang peneliti lakukan yakni bahwa fasilitas layanan belajar memang diperlukan dalam proses pembelajaran sehingga siswa merasa sesuai dengan harapannya ketika ia memilih sekolah tersebut. Penelitian Khorasani (2014) juga mendukung penelitian ini, dengan menggunakan analisis deskriptif menghasilkan temuan bahwa sebagian besar siswa merasa puas dengan fasilitas belajar yang telah disediakan oleh sekolah atau institusi lembaga pendidikannya.

Kontribusi dari fasilitas belajar terhadap kepuasan siswa ditunjukkan berdasarkan perhitungan analisis secara parsial diperoleh $\rho>0.05$ artinya ada kontribusi fasilitas belajar dengan kepuasan siswa. Penelitian ini didukung oleh penelitian sebelumnya yang dilakukan oleh Winahyuningsih (2012)yang nenyatakan bahwa proses pembelajaran dan kualitas pelayanan atas fasilitas belajar dapat mempengaruhi kepuasan peserta didik atau siswa.

Senada dengan penelitian tersebut Manzoor (2013), menyatakan bahwa fasilitas belajar yang diberikan kepada siswa memiliki dampak yang signifikan terhadap kepuasan siswa diperguruan tinggi begitu juga ditingkat sekolah menengah. Lembaga pendidikan bisnisnya bukan hanya sekedar mengajar siswa setiap hari sesuai jadwal, tetapi lebih dari itu. Siswa merasa puas atas layanan fasilitas belajar seperti suasana belajar mengajar yang nyaman, 
adanya perpustakaan, laboratorium, lapangan olahraga, dan sebagainya yang siap memenuhi kepuasan siswa.

Berdasarkan pendapat atau temuan tersebut dapat dimaknai bahwa kepuasan siswa dapat dibangun melalui variabel proses pembelajaran yang memperhatikan kebutuhan siswa. Sementara variabel kualitas pelayanan fasilitas belajar juga dapat meningkatkan kepuasan siswa itu sendiri.

Data variabel motivasi berprestasi menghasilkan rangkuman mean 59,65, median 60,64 dan modusnya 60,89. Data maksimum 72 dan data minimumnya 40, dengan demikian jangkauan data tersebut adalah 32, maka data ini memperlihatkan bahwa penyebaran data tidak simetris, karena jika digambarkan oleh sebuah kurva maka akan cenderung mendekati modusnya.

Mean $<$ Median < Modus, atau 59,65 < 60,64<60,89 maka kurva cenderung menceng kekiri (condong positif), ini memberi makna bahwa sebaran data lebih cenderung ke meannya atau data ini tergolong baik dan posisi responden berada pada motivasi berprestasi yang tidak maksimal.

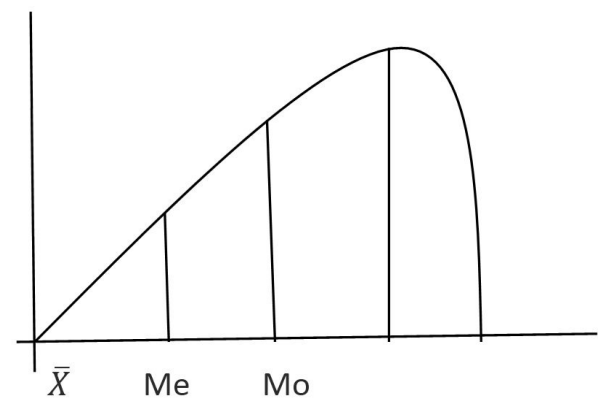

Pada penelitian ini variabel motivasi berprestasi memberikan sumbangan efektif sebesar $11,69 \%$ dan memberikan pula sumbangan relatif sebesar $41,32 \%$ pada signifikansi $\rho=0,092$, artinya semakin baik gairah motivasi berprestasi yang tinggi dari siswa untuk meraih prestasi, maka semakin tinggi pula tingkat kepuasan siswa yang diraihnya.

Kajian motivasi berprestasi, menurut penelitian Heydemans (2010) motivasi berprestasi dalam rangka mencapai prestasi yang maksimal dan menghasilkan kegiatan positif untuk mencapai tujuan tertentu yakni kepuasan dalam belajarnya. Hal ini sejalan pula dengan penelitian yang dilakukan Singh (2011), hasil penelitiannya menunjukkan adanya hubungan antara motivasi berprestasi dengan prestasi akademik yang memberi dampak pada kepuasan siswa. Dikatakan Slameto (2010: 58), bahwa dalam proses belajar mengajar harus memperhatikan apa yang dapat mendorong siswa agar dapat belajar dengan baik atau kepadanya diberikan motiasi untuk berfikir dan memusatkan perhatian, merencanakan dan melaksanakan kegiatan yang berhubungan atau menunjang belajar.

Penelitian membahas adanya kontribusi dari motivasi berprestasi terhadap kepuasan siswa. Berdasarkan perhitungan analisis secara parsial diperoleh nilai $\rho>0.05$ artinya ada kontribusi yang signifikan antara motivasi berprestasi dengan kepuasan siswa.Keunikan penelitian ini adalah bahwa semua siswa menempati asrama yang disediakan oleh sekolah, artinya semua siswa secara tidak langsung menggunakan semua fasilitas belajar yang ada disekolah dalam setiap harinya. Semua siswa dibimbing langsung oleh bagian pengasuhan 
yang didalamnya selalu diberikan motivasi untuk berprestasi setinggi-tingginya, namun pada penelitian ini variabel-variabel unsur-unsur dinamis pembelajaran, fasilitas belajar, dan motivasi berprestasi hanya memberikan kontribusi $27,5 \%$.

\section{PENUTUP}

Terdapat kontribusi yang positif unsur-unsur dinamis pembelajaran, fasilitas belajar, dan motivasi berprestasi terhadap kepuasan siswa.Hasil ini memberi makna bahwa jika unsurunsur dinamis pembelajaran dilaksanakan dengan baik, fasilitas belajar dilengkapi dan diiringi dengan peningkatan motivasi berprestasi baik dari siswa itu sendiri atau dari guru maka akan berkontribusi positif terhadap terhadap kepuasan siswa sebesar 27,5\%.

Terdapat kontribusi yang positif antara unsur-unsur dinamis pembelajaran terhadap kepuasan siswadengan koefisien regresi sebesar 0,282,ini bermakna bahwa jika unsur-unsur dinamis pembelajaran dilaksanakan dengan baik maka akan meningkatkan tingkat kepuasan siswa dan memberikan sumbangan efektif sebesar $6,49 \%$.

Terdapat kontribusi yang positif antarafasilitas belajar terhadap kepuasan siswadengan koefisien regresi sebesar 0,357 ,ini bermakna bahwa jika fasilitas belajar naik 1 satuan, maka akan meningkatkan tingkat kepuasan siswa dan memberikan sumbangan efektif sebesar $9,69 \%$.

Terdapat kontribusi yang positifantaramotivasi berprestasiterhadap kepuasan siswadengan koefisien regresi sebesar 0,630,ini bermakna jika motivasi berprestasiditingkatkandengan baiksebesar 1satuan, maka akan meningkatkan tingkat kepuasan siswa dan memberikan sumbangan efektif sebesar 11,32\%. Oleh karena itu, untuk meningkatkan kepuasan siswa maka MTs Ta' mirul Islam Surakarta harus melaksanakan unsur-unsur dinamis pembelajaran dengan semaksimal mungkin didukung oleh peningkatan sarana fasilitas belajar yang memadahi serta memberikan motivasi yang kuat kepada siswa untuk selalu meraih prestasi setinggi-tingginya secara bersama-sama.

\section{DAFTAR PUSTAKA}

Algifari. 2000. Analisis Regresi (Teori, Kasus dan Solusi ). Yogyakarta:BPFE UGM

Badrudin. 2014. Manajemen Peserta Didik. Jakarta: PT Indeks.

Croxton, R. 2014. The Role of Interactivity In Student Satisfaction and Persistence In Online Learning. Journal of Online Learning and Teaching. 10(2), 314-325.

Dimitrios, G. 2015. The Relation Between Distance Education Students Motivation And Satisfaction. Journal of Distance Education-TOJDE School of Physical Education and Sport Science Democritus University of Thrace, 16(2), 13-17.

Ehsan, M. 2010. The Impact of Service Quality on Students' Satisfaction in Higher Education Institutes of Punjab. Journal of Management Research. 2(2), 1-11.

Fahdita, Rita. 2010. "Kompetensi Pengelolaan Pembelajaran, Kecerdasan Interpersonal, Komitmen dan Kepuasan Kerja Guru SMK". Jurnal Ilmu Pendidikan. FT UNM . 18(1), 30-35.

Fita, A. 2014. Pengaruh Kualitas Pelayanan Akademik terhadap Kepuasan Mahasiswa BKK Pendidikan Akuntansi Program Studi Pendidikan Ekonomi FKIP Universitas Sebelas 
Maret Surakarta. Jurnal Pendidikan UNS, 2(3), 211-223.

Khorasani. 2014. A Study On Student's Satisfaction Towards The Campus Transit System In University Sanis Malaysia. International Journal of Research in Business Management. 2(4), 7-16.

Kirmizi, O. 2015. The Influence of Learner Readiness on Student Satisfaction And Academic Achievement in An Online Program At Higher Education. The Turkish Online Journal of Educational Technology. 14(1), 1-11.

Manzoor, H. 2013. Measuring Student Satisfaction in Public and Private Universities in Pakistan, Global Journal of Management and Business Research Interdisciplinary, 13(3), 4-15.

Mulyasana, D. 2011. Pendidikan Bermutu. Bandung: PT Remaja Rosdakarya.

Puspayani, D.N. 2012. “ Kontribusi Sarana Prasarana, Layanan Administratif,Kompetensi Profesional Guru terhadap Kepuasan Belajar ( StudiTentangPersepsi Siswa SMA N 1 Sukawati )".

Jurnal Pendidikan dan Pengajaran Universitas Pendidikan Ganesha. 7(4), 64-76.

Purwanto, N.M. 2014. Psikologi Pendidikan. Bandung: PT Remaja Rosdakarya.

Rahmawati, D. 2013. Analisis Faktor-faktor yang Mempengaruhi Kepuasan Siswa. Jurnal Economia, 9(1),52-60.

Sallis, Edward. 2012. Total Quality Management In Education. Yogyakarta: IRCiSoD.

Sahin, O. 2014. An Investigation of Student Satisfaction Factors. Journal of Research in Business and Managemet. 2(6), 8-1.

Seng, ELK. 2013. A Qualitative Study of International Student's Statisfaction of Institutional Quality. Journal Asian Social Science, 9(13), 126-129.

Singh, K. 2011. Study of Achievement Motivation in Relation to Academic Achievement of Sudents. International Journal of Educational Planning And Administration. 1(2), $161-171$.

Sopiatin, P. 2010. Manajemen Belajar Berbasis Kepuasan Siswa. Bogor: Ghalia Indonesia.

Subana, S. 2011. Dasar-Dasar Penelitian Ilmiah. Bandung: Pustaka Setia.

Sugiyono. 2012. Statistika untuk Penelitian. Bandung:Alfabeta.

Sugiyono, Susanto A. 2015. Cara Mudah Belajar SPSS dan LISREL. Bandung: Alfabeta.

Sundayana, R. 2014. Media dan Alat Peraga Dalam Pembelajaran Matematika. Bandung: Alfabeta.

Sutama. 2015. Metode Penelitian Pendidikan. Kartasura:FairuzMedia.

Syah, P. 2014. Psikologi Pendidikan. Bandung:PT Remaja Rosdakarya Offset.

Uka, A. 2014. Student Satisfaction As an Indicator of Quality in Higher Education. Journal of Educational And Instructional Studies in The World, 4(3), 6-10.

Uno, Hamzah. 2007. Teori Motivasi dan Pengukurannya. Jakarta: Bumi Aksara.

Wijaya, D. 2012. Pemasaran Jasa Pendidikan. Jakarta: Salemba Empat.

Winahyuningsih, P. 2012. Pengaruh Pembelajaran dan Kualitas Pelayanan terhadap Kepuasan 
p-ISSN: 1907-4034

e-ISSN: 2548-6780

dan Loyalitas Mahasiswa Universitas Muria

Kudus. Jurnal Dinamika Ekonomi dan Bisnis. 9(2), 1-18.

Zhu, C. 2012. Student Satisfaction, Performance, and, Knowledge

Construction in Online Collaborative Learning. Journal International

Forum of Educational Technology and Society, 15(1), 127-136. 